The Version of Record of this manuscript has been published and is available in Journal of Environmental Planning and Management, Volume 58, Issue 3, 2015.

Published online: 05 Feb 2014

http://www.tandfonline.com/10.1080/09640568.2013.866544

\title{
Emerging Market Patterns in Recycled Paper Trade
}

\author{
Heli Arminen $^{a^{*}}$, Maija Hujala ${ }^{\mathrm{a}}$, Anni Tuppura ${ }^{\mathrm{a}}$

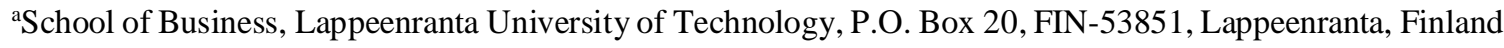 \\ *Corresponding author \\ E-mail addresses: heli.arminen@lut.fi (H. Arminen), maija.hujala@lut.fi (M. Hujala), anni.tuppura@lut.fi \\ (A.Tuppura)
}

\begin{abstract}
The international recovered paper trade serves two important functions: increasing raw material availability in the paper and board industry and providing economic incentives to recycle. The purpose of this paper is to shed further light on emerging patterns in this trade by empirically analysing the changes in the bilateral trade flows of recycled paper between 1992 and 2008. According to our estimations, two important changes have taken place in the 1990s and 2000s. First, the growing importance of developing economies in global recycled paper trade plays a significant role in import demand as a determinant of trade flows. Second, the changes in global trade patterns necessitate investigating the transportation cost measures used in applied research.
\end{abstract}

Keywords: recycled paper; pulp and paper industry; bilateral trade; emerging market economies; panel data 


\section{Introduction}

The global demand for recycled paper for use in paper and board production has been growing continuously during recent decades, and the use of recovered paper now exceeds the use of wood pulp as a raw material (RISI 2012). This development has been facilitated by technological progress in the areas of deinking and screening for impurities (Diesen 2007)

and, especially, by the cost competitiveness of recycled fibre (RISI 2013). In addition, environmental consciousness - for both the producer and consumer - and regulations have contributed to the increase in the demand for waste paper $^{1}$ (e.g., Berglund and Söderholm 2003).

The increased demand for recovered paper is also visible in international trade flows. Waste paper trade has at least two important consequences (Grace, Turner, and Walter 1978). First, imported recovered paper is an important additional source of paper-making fibre for many countries. Second, the opportunity to export recycled materials increases economic incentives to recycle and thus helps reduce environmental damage. Therefore, as the results of Sharma, van Beukering, and Nag (1997) and van Beukering and Duraiappah (1998) imply, trade in recovered paper can be both economically and environmentally advantageous.

The trade of recyclable materials has been claimed to be the fastest growing economic sector worldwide ${ }^{2}$. Although the trade of recyclable materials in general and recovered paper in particular has skyrocketed during the last decades, the subject is understudied in the existing literature. Thus, the results of this study may be of interest to both policymakers and academics by providing information on the evolution of the relationship between trade and sustainable development. 
The purpose of this paper is to shed light on emerging patterns in recycled paper trade. We begin by presenting two central concepts in the recovered paper markets: the recovery rate and the utilisation rate. The increase in recycling activity manifests as an overall rise in these rates in many countries from 1992 to 2010. In addition, the evolution of the paper, board, and recycled paper trades reveals the accelerating demand for paper-making fibre in China and other emerging market economies, while several developed countries have become net exporters of waste paper.

According to international trade theory, the volume of trade is determined by export supply, import demand, and other factors that impact trade either negatively or positively. In the case of recycled paper trade, it is important to notice that the secondary materials market (i.e., the market for recycled paper) is closely associated with the primary materials (i.e., pulp) and final product (i.e., paper) markets (Grace, Turner, and Walter 1978; van Beukering and Bouman 2001; van Beukering and van den Bergh 2006) and that the market equilibrium is formed jointly by all three markets. Therefore, our model of bilateral waste paper trade flows includes explanatory variables from all of these categories. Our results imply that two important changes have taken place in the 1990s and 2000s. First, it appears that recovered paper trade has been driven primarily by its import demand in the 2000s. This result reflects the growing importance of China and other emerging market economies in global trade and could have consequences for the effectiveness of environmental regulations in high-income countries. Second, transportation costs, as measured by distance between trade partners, seem to have stopped curtailing the bilateral recovered paper trade in the 2000s. Thus, it is important to develop and utilise other measures of transportation costs, particularly in the context of goods that are exported to China and other similar major exporters. 


\section{Recycled Paper Recovery and Utilisation Trends}

Recovered paper utilisation is both supply and demand driven and is determined by economics and politics (Berglund, Söderholm, and Nilsson 2002; Berglund and Söderholm 2003). The use of recycled paper as raw material for paper-making began increasing in the early 1970s and increased 575\% between 1970 and 2010 (RISI 2012). There are several reasons for the notable growth: scarce landfill capacity in many countries, fear of virgin wood shortage in the 1960s and 1970s, technological development, and growing environmental awareness (see, e.g., Collins [1998]). Currently, recycled paper is used as raw material in the paper industry when it is available and its usage is economically rational (Berglund, Söderholm, and Nilsson 2002; Berglund and Söderholm 2003). While waste paper collection quickly becomes uneconomic in sparsely populated areas, it appears to be feasible to export waste paper even far afield when the domestic supply exceeds the demand.

Figure 1 depicts the production and consumption of recycled paper by region between 1970 and 2012. Production depicts an increasing trend everywhere. The figure also clearly shows that by far the largest increase of consumption has occurred in Asia. The simultaneous increase in waste paper recovery was far smaller than the rise in consumption in the region, meaning that Asia, and China in particular, have become progressively less self-sufficient in recovered paper supply. As a consequence, Asia has come to increasingly rely on massive imports of recycled paper from North America and Western Europe. In 2010, China accounted for $57 \%$ of Asia's demand for recycled paper and $75 \%$ of the imports. Western Europe and especially North America are the largest waste paper exporters. North America's 
domestic demand for recovered paper has declined along with decreasing demand for newsprint and stagnating demand for packaging materials in the United States. According to RISI (2012), there were over 54 million tonnes of recovered paper exports in 2010, making it the most exported raw material in the pulp and paper industry.

[Figure 1 near here]

A country's status with respect to recycled paper can be described by two ratios (e.g., Grace, Turner, and Walter 1978). First, the portion of a country's paper consumption entering the recovered paper market is called the recovery rate $(R R)$. It is calculated by dividing the domestic recycled paper production $(R P Q)$, i.e., collection, by the total domestic paper and board consumption $(P B C)$ :

$$
R R=\frac{R P Q}{P B C}
$$

Second, the utilisation rate $(U R)$ measures the extent to which recycled paper is used in paper and board production. It is calculated by dividing a country's recovered paper consumption $(R P C)$ by its total domestic paper and board production $(P B Q)$ :

$$
U R=\frac{R P C}{P B Q}
$$

In a closed economy, $R R$ equals $U R$ because it then holds that $R P Q=R P C$ and $P B C=P B Q$. International trade in waste paper can thus be observed as the difference in the observed recovery and utilisation rates for a country. The differences in the ratios are caused by (1) 
trade in paper and board and (2) trade in recycled paper (Grace, Turner, and Walter 1978; Collins 1996).

As in Grace, Turner, and Walter (1978), we next plot the recovery rates against the utilisation rates for the 25 largest recycled paper consumers for which all the data necessary for Figures 2 and 3 were available. Figure 2 depicts the changes in the relationships between the two rates between 1992 and 2010.

[Figure 2 near here]

In general, the farther from the origin and the closer to the top right-hand corner a country lies, the more it recycles. In 2010, the recovery rates were highest in South Korea (96\%) and Switzerland (83\%) and lowest in India (28\%). Inter-country differences in the utilisation rate were tremendous, varying from $16 \%$ in Sweden to $100 \%$ in Malaysia. The lowest utilisation rates were found in forest-rich northern countries that have traditionally been significant exporters of paper and board products (e.g., Sweden, Russia, Canada and USA in Figure 2).

The general movement toward the top right-hand corner depicted by the arrows indicates that there was an overall increase in the recovery and utilisation rates in most of these countries between 1992 and 2010. This trend favours sustainable development. In fact, some countries show vast advances in recycling activity. For example, the recovery rate increased by over 50 percentage points in South Korea and by over 40 percentage points in Australia and the United Kingdom. The recovery rate increased by an average of 24 percentage points in the 25 countries depicted in Figure 2. Many countries also show greater than 25 percentage point increases in the utilisation rate, which rose by 40 percentage points 
in Turkey, 39 percentage points in Malaysia and China and 38 percentage points in Belgium. In Thailand, the utilisation rate decreased by 12 percentage points. On average, the change in the utilisation rate was +15 percentage points.

In China, the recovery rate grew from $25.5 \%$ to $45.3 \%$ and the utilisation rate from $33.0 \%$ to $71.6 \%$. The change in percentage points was even larger in Malaysia for both ratios. Other emerging market economies showed significant increases in one of the ratios and smaller in the other. For example, in Indonesia, the recovery rate rose by 36 percentage points and the utilisation rate by only 4 percentage points, while in India, the utilisation rate increased by 19 percentage points and the recovery rate by 9 percentage points. Thus, there are significant differences in how the ratios have evolved in different countries. These differences should also be reflected in the international trade flows of recycled paper over time.

Figure 3 also follows Grace, Turner, and Walter (1978). The four quadrants of the coordinates represent different trade patterns of countries with respect to (1) trade in paper and board $(P \& B)$ and (2) trade in recycled paper $(R P)$. Countries situated in the first quadrant (such as China in 1992) are net importers of paper and board and of recovered paper. The second quadrant represents those countries (such as Belgium in 1992) that are net importers of paper and board but net exporters of recycled paper. Countries located in the third quadrant are net exporters of paper and board and of waste paper. Finally, the countries in the fourth quadrant, such as Sweden, are net exporters of paper and board but net importers of recycled paper.

[Figure 3 near here] 
Focusing on the data from 2010, Figure 3 shows that four countries, Canada, USA, Switzerland and Russia, were net exporters of both paper and board and recycled paper. Apart from Switzerland, these countries have vast virgin fibre resources and thus had the lowest utilisation rates in 2010 along with Sweden (Figure 2). Interestingly, Sweden was a net importer of recycled paper despite its low utilisation rate. This finding indicates that Sweden's domestic waste paper collection did not meet the demand for recovered fibre in paper-making. The first quadrant of Figure 4 includes four emerging market economies (Turkey, Malaysia, Mexico and India) and Spain, whereas there are eight high-income countries in the second quadrant. Turkey, Malaysia, Mexico, India, and Spain all lie below the 45-degree line in Figure 2, and with the exception of Spain, their recovery rates were relatively low in 2010. Instead, the countries in the second quadrant of Figure 3 are located on both sides of the 45-degree line in Figure 2 and are relatively close to it, with the exception of Australia.

Some changes in the patterns of trade occurred between 1992 and 2010. First, China's net imports of recycled paper relative to its recovery in the country soared from $15 \%$ in 1992 to $60 \%$ in 2010 . This development was mostly caused by a vast increase in recovered paper imports to China. Second, Malaysia changed from a net exporter of waste paper to a net importer. Third, Germany experienced a drastic change from net importer to net exporter in the case of paper and board and the opposite transformation from net exporter to net importer for recycled paper. Fourth, Canada transformed from a net importer of waste paper to a net exporter due to an increase in the recovery rate. Finally, France, Italy, Netherlands, Poland and Japan became net exporters of recycled paper. On one hand, these figures reflect a huge 
demand for recycled paper in China and other emerging market economies and on the other hand show the recycling targets employed in many Western countries. For example, in 2003, the Canadian Forest Products Association set a target to increase the recovery rate to $55 \%$ by the year 2010 .

\section{Research Methodology}

\subsection{A Model of Recycled Paper Trade}

A commonly used tool in the international trade context is the gravity model of trade introduced by Tinbergen (1962), Pöyhönen (1963) and Linnemann (1966). In the simplest form of the model,

$$
\begin{aligned}
& \ln T_{i j}=\beta_{0}+\beta_{1} \ln G D P_{i}+\beta_{2} \ln G D P_{j}+\beta_{3} \ln P O P_{i}+\beta_{4} \ln P O P_{j}+\beta_{5} \ln D_{i j}, \\
& +\beta_{6} \ln X_{i j}+\varepsilon_{i j}
\end{aligned}
$$

where the volume of trade $T$ is defined by the supply conditions in the exporting country $i$ (gross domestic product GDP and population $P O P$ ), the demand conditions in the importing country $j$ (GDP and population), bilateral trade resistance factors (such as the costs of trade, usually approximated by the geographical distance between the trading partners $D$ ), and trade preference factors $X_{i j}$ (such as a common border or a common language). Although the early gravity model contributions were criticised for not having a proper theoretical foundation, it has since been demonstrated that the gravity model can be derived from various models of international trade, including the Ricardian, Heckscher-Ohlin and increasing-returns-to-scale models (Anderson 1979; Bergstrand 1985, 1989, 1990; Helpman and Krugman 1985; Anderson and van Wincoop 2003). 
In particular, the volume of the recycled paper trade depends on the export supply and import demand of waste paper by the bilateral trade partners (see also Michael [1998]). Export supply equals domestic supply minus domestic demand, and import demand is the difference between domestic demand and domestic supply. This implies that all factors that affect demand and supply have an impact. As Polyakov and Teeter (2007) have noted, GDP is generally not a good proxy for import demand and export supply of any single commodity. Thus, in analysing the trade of a single commodity, it is important to use such explanatory variables that affect the supply and demand of that particular commodity. Therefore, Dascal, Mattas, and Tzouvelekas (2002) included production indices of wine in their model of EU wine exports and imports, while Koo, Karemera, and Taylor (1994) used farm income and number of animals in exporting and importing countries to measure livestock production capacity when investigating the trade of meat. In a study more closely associated with ours, Polyakov and Teeter (2007) used data on the production (supply) and consumption (demand) of pulpwood as the determinants of export supply and import demand, respectively. Zhang and Li (2009) explained China's wood products trade by using roundwood production (per capita) and Chinese logging restrictions as the measures of export supply and import demand. In another recent paper, Hujala et al. (2013) focused on the trade of pulp and used various explanatory variables that reflect its import demand, export supply and the costs of trade.

Special features of the trade of recycled paper must also be considered. As Grace, Turner, and Walter (1978), van Beukering and Bouman (2001) and van Beukering and van den Bergh (2006) demonstrated, the secondary materials market (i.e., the market for recovered paper) is closely associated with the primary materials (i.e., pulp) and final product (i.e., paper) markets. Thus, the equilibrium is formed jointly by all three markets. There are 
two implications of this relationship. First, the import demand and export supply of waste paper do not depend only on the factors that influence its demand and supply but also on those that affect its substitutes' (i.e., pulp's) demand and supply. Second, the demand and supply for the final product, paper, also play a role.

Our baseline model is in accordance with Polyakov and Teeter (2007):

$$
\begin{aligned}
& \ln T_{i j t}=\beta_{0}+\beta_{1} \ln T_{i j t-1}+\beta_{2} \ln P O P_{i t}+\beta_{3} \ln P O P_{j t}+\beta_{4} \ln P U L P Q_{i t}+\beta_{5} \ln P U L P Q_{j t} \\
& +\beta_{6} \ln R P Q_{i t}+\beta_{7} \ln R P Q_{j t}+\beta_{8} \ln P B Q_{i t}+\beta_{9} \ln P B Q_{j t}+\beta_{10} \ln D_{i j}+\beta_{11} B O R D E R_{i j} \\
& +\tau_{t}+\eta_{i j}+\varepsilon_{i j t} .
\end{aligned}
$$

The dependent variable $T_{i j t}$ is waste paper exports (in tonnes) from country $i$ to country $j$ in year $t$. The explanatory variables include lagged waste paper exports, population (POP), production of pulp (PULPQ), production of recovered paper $(R P Q)$, production of paper and board $(P B Q)$, distance $(D)$ and a dummy variable for having a common border (BORDER). In addition, year dummies represented by the time effect $\tau_{t}$ are included in the equation to reduce autocorrelation. All variables except the dummy variables are expressed as natural logs. Regression coefficients are assumed to be common to all country pairs. The term $\eta_{i j}$ represents country-pair fixed effects and captures such time-invariant factors that are not included in the model. Finally, $\varepsilon_{i j t}$ is the error term.

As De Benedictis, De Santis and Vicarelli (2005) noted, bilateral trade between any two countries is likely to exhibit inertia due to the sunk costs of, for example, setting up distribution networks. International trade is thus a dynamic process where the past (i.e., lagged) values of trade flows affect the current ones. This is also a plausible assumption in the context of recovered paper trade because the yearly wood pulp supply is relatively stable, as is the demand for the final product. Therefore, we expect the volume of waste paper 
exports to exhibit at least some persistence, indicating that the coefficient of $\ln T_{i j t-1}$ should be positive.

The equation also controls for the populations of the countries. The exporter's population $P O P_{i}$ impacts the export supply of recycled paper and, similarly, $P O P_{j}$ affects the importer's import demand. The impact of population is twofold: population growth increases both the demand for paper and the supply of waste paper, meaning that the expected signs of $\beta_{2}$ and $\beta_{3}$ are unclear.

The production of pulp $(P U L P Q)$ reflects the availability of wood pulp, which is an imperfect substitute for recovered paper in paper and board production. Thus, the larger $P U L P Q$ is, the higher the supply of pulp and the less recycled paper is needed in paper production, indicating that the coefficient of $P U L P Q_{i}$ should be positive. In contrast, the coefficient of the importer's pulp production $P U L P Q_{j}$ is expected to be negative because paper-producing countries with more wood pulp available are less likely to need to import recovered paper for paper and board production.

Recovered paper production $(R P Q)$ and consumption are the factors that affect the export supply and import demand of recovered paper. In theory, both variables should be included in the model. However, they are so highly correlated that one of them must be excluded from the analysis to avoid multicollinearity; therefore, we use only $R P Q$. The higher the production of waste paper, the more of it can be exported or the less of it needs to be imported. Therefore, $\beta_{6}$ is expected to be positive and $\beta_{7}$ negative. $R P Q$ is highly likely to be endogenous in our model, which must be taken into account when choosing the estimation method. 
Finally, the total paper and board production $(P B Q)$ reflects the demand for recovered paper as a raw material. The higher the demand in the exporter, the less it can export (i.e., the lower the export supply), and the higher the demand in the importer, the more it will need to import (i.e., the higher the import demand). Thus, $\beta_{8}$ is expected to be negative and $\beta_{9}$ positive.

As Grace, Turner, and Walter (1978) emphasised, transportation costs play an important role in the trade of recycled materials because their value per unit weight or volume is generally low. In the international trade literature, the distance between any two countries is generally used as a proxy for transportation costs. We measure distance $(D)$ using the distance measures provided by Mayer and Zignago (2011). ${ }^{3}$ Because distance is a proxy for not only transportation costs but also other transaction costs, such as costs of acquiring information or costs of finding a trading partner (Wang, Wei, and Liu 2010), it should reduce the volume of exports. Therefore, the expected sign of $\beta_{10}$ is negative.

Another variable that controls for the ease of trading is the border dummy (BORDER), which takes a value of 1 if countries $i$ and $j$ share a common border and is 0 otherwise. Neighbouring countries tend to trade more with each other, indicating that $\beta_{11}$ should be positive.

In its traditional form, the gravity model does not include any prices as explanatory variables. However, as Bergstrand (1985) demonstrated via a general equilibrium world trade model, prices affect trade flows and should also be considered. Model 5 therefore adds prices to the baseline model: 


$$
\begin{aligned}
& \ln T_{i j t}=\beta_{0}+\beta_{1} \ln T_{i j t-1}+\beta_{2} \ln P O P_{i t}+\beta_{3} \ln P O P_{j t}+\beta_{4} \ln P U L P Q_{i t}+\beta_{5} \ln P U L P Q_{j t} \\
& +\beta_{6} \ln R P Q_{i t}+\beta_{7} \ln R P Q_{j t}+\beta_{8} \ln P B Q_{i t}+\beta_{9} \ln P B Q_{j t}+\beta_{10} \ln D_{i j}+\beta_{11} B O R D E R_{i j} \\
& +\beta_{12} \ln P S U B S T_{i t}+\beta_{13} \ln P S U B S T_{j t}+\beta_{14} \ln P R A T I O_{i j t}+\tau_{t}+\eta_{i j}+\varepsilon_{i j t .}
\end{aligned}
$$

The prices of pulp, recovered paper and paper and board can all affect recycled paper trade flows. The relative prices are crucial. The relative price of recovered paper and pulp (PSUBST, calculated as the price of recovered paper divided by the price of pulp) influences the relative demand for recovered paper and pulp in paper and board production. If $P S U B S T$ increases, the relative price of recovered paper increases, meaning that its demand decreases and more pulp is used in paper and board production. This manifests as an increase in the export supply of recovered paper in the exporter or as a decrease in its import demand in the importer. $\beta_{12}$ is thus expected to be positive and $\beta_{13}$ negative. Second, the relative price of recovered paper in the exporter and the importer (PRATIO) also plays a role (see, e.g., Koo, Karemera, and Taylor [1994] and Dascal, Mattas, and Tzouvelekas [2002] on the importance of export and import prices in explaining the bilateral trade flows of a single commodity). An increase in PRATIO is caused either by an increase in the export price of recovered paper in the exporter (which increases its export supply) or a decrease in the importer's import price (which increases the import demand for recycled paper). Because both the export price and the import price are in current US dollars, PRATIO also measures the evolution of competitiveness by capturing the impact of exchange rate fluctuations. A depreciation of the exporter's currency against that of the importer improves the competitiveness of the exporter and leads to an increase in PRATIO. Therefore, a rise in PRATIO should increase exports. The price of paper and board is not included in the estimations because it is already reflected in paper and board production, the volume of which defines the demand for recovered paper. 
We are particularly interested in the changes in the patterns of the recovered paper trade. Thus, we estimate two separate equations: one for the 1990s (more specifically, 19921999 due to data availability) and another for the 2000s (2000-2008). This division is chosen to obtain two samples of approximately the same size. Moreover, there is evidence that the patterns of the recycled paper trade changed between the two decades: as Figure 1 implies, the gap between Asian consumption and production of recycled paper started to widen at the end of the 1990s, and North American consumption started to decline in 2000.

\subsection{Data Description}

The time period in the empirical analysis is $1992-2008$, which is dictated by the availability of bilateral trade data. The data on the production of wood pulp, recovered paper and paper and board originate from the Industry Statistics database of RISI (2012). The annual bilateral trade flows of recycled paper come from RISI as well and are only available from 1992 to 2008. Population data are sourced from the World Development Indicators database (World Bank 2012). The population-weighted measure of distance between the bilateral trade pairs originates from Mayer and Zignago (2011), and the border dummies come from a database provided by Andrew K. Rose. Due to data availability, we use the export prices of pulp and recovered paper as proxies for domestic market prices. The prices have been calculated by dividing the value of exports (in 1000 current US dollars) by the volume of exports (in tonnes) and multiplying by 1000. The values and volumes of exports (and imports, for the calculation of PRATIO) originate from FAO (2013).

Summary statistics for the variables are presented in Table 1 for the countries used in the analysis. The waste paper exporters comprise Austria, Belgium, Canada, Denmark, 
Finland, France, Germany, Greece, Ireland, Italy, Japan, Netherlands, Norway, Portugal, Russia, Spain, Sweden, Switzerland, the United Kingdom and the United States (these are the countries for which bilateral trade data are available from the 1990s and 2000s), while the number of importers is larger and varies across years due to data availability.

[Table 1 near here]

\subsection{Estimation Method}

Panel data models have become increasingly popular in international trade analyses. They make it easier to control for heterogeneity: for example, Micco, Stein, and Ordoñez (2003) and Cheng and Wall (2005) stressed that panel data econometrics that take individual effects into account reduce the heterogeneity bias. However, there are some issues that need to be taken into account when choosing the estimation method. In particular, it is important to take the potential endogeneity of the explanatory variables into account. As defined in Bond (2002), a variable $x_{i j t}$ is endogenous if it is correlated with $\varepsilon_{i j t}$ and earlier shocks, but uncorrelated with $\varepsilon_{i j, t+1}$ and subsequent shocks. A variable is predetermined if it is uncorrelated with $\varepsilon_{i j t}$ but correlated with $\varepsilon_{i j, t-1}$ and earlier shocks. If $x_{i j t}$ is exogenous, it is uncorrelated with all past, present and future realisations of $\varepsilon_{i j s}$.

We control for endogeneity by using a dynamic panel general method of moments (GMM) estimator. The estimator by Arellano and Bond (1991), also called the difference GMM, is an instrumental variables estimator designed for panel data. As the name implies, difference GMM uses lagged predetermined and endogenous variables as instruments for those predetermined and endogenous variables in first differences. An alternative to the 
difference GMM estimator is the system GMM estimator (Arellano and Bover 1995; Blundell and Bond 1998), which adds the original equations in levels into the system of firstdifferenced equations. The validity of the additional instruments hinges on the assumption that changes in the instrumenting variables are uncorrelated with the fixed effects. The difference-in-Hansen test can be used to test the validity of a subset of instruments (Roodman 2009). For example, De Benedictis, De Santis and Vicarelli (2005) used the system GMM to estimate a gravity model. Roodman (2009) discussed the difference and system GMM more extensively.

The lagged levels of the series provide only weak instruments for subsequent first differences with persistent time series (Blundell and Bond 1998; Bond, Hoeffler, and Temple 2001), which is a problem in difference GMM estimations. In such a case, the system GMM estimator performs better. In addition, the system GMM does not drop time-invariant explanatory variables (such as distance) and is thus more suitable for our purposes.

The number of instruments is quadratic in the number of time periods, which is problematic because having too many instruments tends to overfit endogenous variables. In our models, the number of lags of the instrumenting variable is thus restricted. Moreover, the one-step GMM estimator is efficient only under homoskedasticity and uncorrelated error terms, while the two-step estimator is asymptotically more efficient. However, the two-step estimates of the standard errors tend to be biased downward (Arellano and Bond 1991; Blundell and Bond 1998). Therefore, a finite-sample correction for the asymptotic variance of the two-step GMM estimator of Windmeijer (2005) is used in all estimations. All analyses are conducted with Stata/IC software (version 11.2 for Windows). The Stata module 
xtabond 2 by Roodman (2009) is used to correct for the downward bias in the two-step estimates of the standard errors and to reduce the number of instruments.

\section{Estimation Results}

The two-step system GMM estimation results for the 1990s are presented in Table 2, models 1 and 2, and the results for the 2000s are shown in Table 2, models 3 and 4. Models 1 and 3 are based on equation 4, while models 2 and 4 are based on equation 5 with all different prices included. The endogenous explanatory variables comprise the production of recycled paper (in the exporter and the importer) and the price ratios. The lagged dependent variable is predetermined, as usual. Other predetermined variables are the production of pulp and the production of paper and board (in the exporter and the importer). The population (in the exporter and the importer), distance, border dummy and year dummies are treated as exogenous. The number of lags of the instrumenting variable in the transformed equation is restricted to lags 2-4 for the endogenous variables and lags 1-3 for the predetermined variables in models 1 and 3 and to lags $2-3$ for the endogenous variables and lags $1-2$ for the predetermined variables in models 2 and 4.

The test results depicted at the bottom of Table 2 indicate that 1) there is no secondorder autocorrelation in the first-differenced residuals (second-order correlation in differences would imply first-order autocorrelation in levels, which would be a problem in the estimations), but, as expected, there is first-order autocorrelation; 2) the set of instruments is valid, i.e., the instruments are exogenous (but only at the 5\% level in model 3); 3) the level moment conditions imposed in the system GMM estimation are valid in models 2 and 4, but 
there are some problems with the baseline model estimations; and 4) the instrument group formed from the exogenous regressors is also valid, i.e., the instruments in question are not correlated with the error term. It should be noted that all the problematic test statistics are associated with the baseline model, while we are more interested in the augmented model. We also used orthogonal deviations ${ }^{4}$ instead of first-differencing (the results are available upon request) with results that are completely in line with the estimation results presented below.

[Table 2 near here]

To begin, we will focus on the situation in the 1990s, i.e., models 1 and 2 . As expected, the lagged recovered paper exports have a positive coefficient that is statistically significant at the $1 \%$ level, implying that there is persistence in waste paper trade flows. The exporter's population is statistically insignificant in both models, whereas the importer's population is statistically significant at the $1 \%$ level. Thus, it appears that population growth in the importer increased the demand for paper and, consequently, for paper-making fibres such as recovered paper in the 1990s. Regarding distance, the coefficient of the variable is negative and statistically significant at the $1 \%$ level, indicating that transportation costs reduced the volume of recovered paper trade between two countries in the 1990s. The negative effect was most likely strengthened by the relatively high transportation cost to product value ratio, especially for the lower grades of waste paper. The border dummy is also statistically significant at the $1 \%$ level. The positive coefficient indicates that countries sharing a common border tended to trade more with each other. 
Surprisingly, the production of pulp, recovered paper and paper and board are all statistically insignificant, even at the $10 \%$ level, with the exception of the production of pulp in the importer, which has a negative coefficient (as expected) and is statistically significant at the 5\% level. The relative prices of recovered paper and pulp and the relative price of recovered paper in the exporter and the importer are statistically insignificant. These results are robust to including only some of the price variables in the model (the results are available upon request). The insignificance of the relative price of recovered paper and pulp could indicate limited substitutability between waste paper and wood pulp in paper and board production (see also van Beukering and Bouman [2001]).

As mentioned earlier, we are particularly interested in the change between the two decades. In the 2000s (models 3 and 4), lagged recovered paper exports continued to have a statistically significant positive impact on the volume of waste paper exports, which supports some degree of persistence in the volume of trade. The exporter's population was again statistically insignificant, while the importer's population continued to have the same positive impact on the bilateral trade flows as it did in the 1990s. Interestingly, while the exporter's production of pulp, recovered paper and paper and board continued to be statistically insignificant, the variables measuring production in the importer were all statistically significant at the $10 \%$ level, at least, with the expected signs. This implies that recovered paper trade was driven more by import demand than export supply in the 2000s. This highlights the role of countries with the fastest increases in paper and board production. The descriptive analysis of section 2 implies that these countries are mainly emerging market economies, with China as a particularly dominant player in the market. 
There is another important change between the two decades: transportation costs as measured by distance seemed to lose their trade-hampering nature by the 2000 s. One possible explanation is that freight rates to certain major exporters of industrial and manufacturing goods, such as China, were much lower - independent of distance - because of the surplus freight space on ships returning empty to these destinations after delivering their exported products. ${ }^{5}$ As a result, the transport costs for recyclable materials declined and had little impact on the trade flows. It is also likely that the demand for recycled paper was so strong in some countries that the costs of getting the raw material to the paper and board industry were secondary concerns. Our descriptive analysis of Section 2 again implies that these countries are mostly emerging market economies. Instead, the border dummy variable was still statistically significant at the 5\% level, at least, indicating that neighbouring countries continued to trade more with each other in the 2000s.

The relative price of recovered paper and pulp continued to be statistically insignificant, again implying limited substitutability between waste paper and wood pulp. The relative price of recovered paper in the exporter and the importer was also statistically insignificant.

\section{Conclusions}

In this paper, we examined the international trade flows in recycled paper. This trade serves two important functions: increasing raw material availability in the paper and board industry and providing economic incentives to recycle, which thereby helps to reduce environmental 
damage. Despite significant changes in waste paper trade flows in recent decades, the subject remains understudied in the existing literature.

Our model builds on the theory of international trade, which states that the volume of trade is determined by export supply, import demand, and other factors that affect trade. In the case of a single-product trade model, it is important to include relevant factors that impact the product's export supply and import demand. The market equilibrium for recovered paper trade is formed jointly by three markets: the recovered paper (secondary material), pulp (primary material), and paper (final product) markets. The dynamic nature of the recycled paper trade and the endogeneity of some of the explanatory variables must be considered in the choice of estimation methodology. Therefore, we use the system GMM estimator. Because we are particularly interested in changes in the patterns of the waste paper trade, we estimated the models separately for the 1990s and the 2000s.

According to our results, two important changes occurred between the 1990s and the 2000s. First, it appears that unlike in the 1990s, the recovered paper trade in the 2000s is predominantly driven by its import demand. This result is most likely due to the growing importance of China and other emerging market economies in the global waste paper trade. This finding implies that high-income countries could be in a position where they have very little control over the demand for their recovered paper. Therefore, their influence on the global utilisation of waste paper is also limited. Along with the evidence that the motives for paper recovery and utilisation differ between developed and developing economies (see, e.g., Arminen et al. [2013]), this indicates that in the future, the environmental attitudes in lowerincome countries will be decisive to the scale of global waste paper recovery and trade. 
Second, transportation costs seem to have become insignificant in determining bilateral recovered paper trade flows in the 2000s. This result likely reflects changes in the overall patterns of international trade. In particular, freight rates to certain major exporters (such as China) are currently relatively low, independent of distance, because of the surplus freight space of ships returning to these destinations empty after delivering exported products. Therefore, it is important to develop and begin using other measures of transportation costs, particularly in the context of goods that are exported to China and other similar major exporters. These measures should consider that the transportation costs may differ depending on the direction of trade flow. They should also account for the mode of transport.

Further changes are expected in the global patterns of the recovered paper trade. For example, it is likely that the current economic slowdown will affect the trade flows of recycled paper through at least two channels. First, the slowdown may decrease paper consumption in countries that export waste paper, which reduces the availability of recycled fibre. Second, slower economic growth in China and other emerging market economies may decrease the demand for recycled fibre. This possibility is particularly significant from the point of view of global waste paper trade because our results imply that the recycled paper trade in the 2000s has been driven by import demand from lower-income countries. Additionally, the increasing availability and popularity of online and mobile content may decrease paper consumption not only in the Western countries but also in emerging market economies, which will impact the supply of waste paper in the future. These changes are interesting topics for further research concerning the recycled paper trade. 


\section{Endnotes}

[1] The terms recycled paper, recovered paper and waste paper are used interchangeably in this paper.

[2] We thank the reviewer for pointing this out.

[3] Mayer and Zignago (2011) make available four measures of bilateral distance. First, they provide simple distances (in kilometres) between two cities only, with the cities in question being either the official capitals or the most populated cities of the country pairs. Second, they provide two distance measures that are weighted by the shares of the principal cities in the country's total population, which thus build on the geographical distribution of population inside the countries. See Mayer and Zignago (2011) for a more detailed description.

[4] The orthogonal deviations transform proposed by Arellano and Bover (1995) is an alternative to differencing. This method subtracts the average of all available future observations instead of the previous observation and is particularly useful with unbalanced panels because it preserves the sample size, despite gaps in the data (Roodman 2009). Taking orthogonal deviations removes the country-pair specific effects, similar to differencing.

[5] We thank the reviewers for pointing this out.

\section{References}

Anderson, James E. 1979. “A Theoretical Foundation for the Gravity Equation.” American Economic Review 69 (1): 106-16. 
Anderson James E., and Eric van Wincoop. 2003. "Gravity with Gravitas: A Solution to the Border Puzzle." American Economic Review 93 (1): 170-92.

Arellano, Manuel, and Stephen Bond. 1991. "Some Tests of Specification for Panel Data: Monte Carlo Evidence and an Application to Employment Equations." Review of Economic Studies 58 (2): 277-97.

Arellano, Manuel, and Olympia Bover. 1995. "Another look at the instrumental variable estimation of error-components models.” Journal of Econometrics 68 (1): 29-51.

Arminen, Heli, Maija Hujala, Kaisu Puumalainen, Anni Tuppura, and Anne Toppinen. 2013. "An update on inter-country differences in recovery and utilization of recycled paper." Resources, Conservation and Recycling 78: 124-35.

Berglund, Christer, Patrik Söderholm, and Mats Nilsson. 2002. “A Note on Inter-Country Differences in Waste Paper Recovery and Utilization." Resources, Conservation and Recycling 34 (3): 175-91.

Berglund, Christer, and Patrik Söderholm. 2003. “An Econometric Analysis of Global Waste Paper Recovery and Utilization." Environmental and Resource Economics 26 (3): 429-56.

Bergstrand, Jeffrey H. 1985. "The Gravity Equation in International Trade: Some Microeconomic Foundations and Empirical Evidence." Review of Economics and Statistics 67 (3): 474-81.

Bergstrand, Jeffrey H. 1989. “The Generalized Gravity Equation, Monopolistic Competition, and the Factor-Proportions Theory in International Trade." Review of Economics and Statistics 71 (1): 143-53. 
Bergstrand, Jeffrey H. 1990. "The Heckscher-Ohlin-Samuelson Model, the Linder Hypothesis and the Determinants of Bilateral Intra-Industry Trade.” Economic Journal 100 (403): 1216-29.

Blundell, Richard, and Stephen Bond. 1998. "Initial Conditions and Moment Restrictions in Dynamic Panel Data Models.” Journal of Econometrics 87 (1): 115-43.

Bond, Stephen. 2002. "Dynamic Panel Data Models: A Guide to Micro Data Methods and Practice.” Portuguese Economic Journal 1 (2): 141-62.

Bond, Stephen, Anke Hoeffler, and Jonathan Temple. 2001. GMM Estimation of Empirical Growth Models. CEPR Discussion Paper No. 3048. London: Centre for Economic Policy Research.

Cheng, I-Hui, and Howard J. Wall. 2005. “Controlling for Heterogeneity in Gravity Models of Trade and Integration." Federal Reserve Bank of St. Louis Review 87 (1): 49-63.

Collins, Lyndhurst. 1996. "Recycling and the Environmental Debate: A Question of Social Conscience or Scientific Reason?." Journal of Environmental Planning and Management 39 (3): 333-55.

Collins, Lyndhurst. 1998. "Environmentalism and Restructuring of the Global Pulp and Paper Industry.” Tijdschrift voor Economische en Sociale Geografie 89 (4): 401-15.

Dascal, Dana, Konstadinos Mattas, and Vangelis Tzouvelekas. 2002. "An Analysis of EU Wine Trade: A Gravity Model Approach.” International Advances in Economic Research 8 (2): $135-47$. 
De Benedictis, Luca, Roberta De Santis, and Claudio Vicarelli. 2005. "Hub-and-Spoke or else? Free trade agreements in the 'enlarged' European Union." European Journal of Comparative Economics 2 (2): 245-60.

Diesen, Magnus. 2007. Paper Making Science and Technology: Economics of the Pulp and Paper Industry. Jyväskylä, Finland: Paperi ja Puu Oy.

FAO. 2013. ForesSTAT database. Accessed August 15, 2013.

http://faostat.fao.org/site/626/default.aspx\#ancor

Grace, Richard, R. Kerry Turner, and Ingo Walter. 1978. "Secondary Materials and International Trade.” Journal of Environmental Economics and Management 5 (2): 172-86.

Helpman, Elhanan, and Paul R. Krugman. 1985. Market Structure and Foreign Trade: Increasing Returns, Imperfect Competition, and the International Economy. Cambridge, MA: MIT Press.

Hujala, Maija, Heli Arminen, R. Carter Hill, and Kaisu Puumalainen. 2013. "Explaining the Shifts of International Trade in Pulp and Paper Industry." Forest Science 59 (2): 211-22.

Koo, Won W., David Karemera, and Richard Taylor. 1994. “A Gravity Model Analysis of Meat Trade Policies.” Agricultural Economics 10 (1): 81-8.

Linnemann, Hans. 1966. An Econometric Study of International Trade Flows. Amsterdam: North-Holland.

Mayer, Thierry, and Soledad Zignago. 2011. Notes on CEPII”s distances measures: The GeoDist database. CEPII Working Paper No. 2011-25. Paris: CEPII. 
Micco, Alejandro, Ernesto Stein, and Guillermo Ordoñez. 2003. "The Currency Union Effect on Trade: Early Evidence from EMU.” Economic Policy 18 (37): 315-56.

Michael, Jeffrey A. 1998. "Recycling, International Trade, and the Distribution of Pollution: The Effect of Increased U.S. Paper Recycling on U.S. Import Demand for Canadian Paper.” Journal of Agricultural and Applied Economics 30 (1): 217-23.

Polyakov, Maksym, and Lawrence Teeter. 2007. "Modeling Pulpwood Trade Within the United States South.” Forest Science 53 (3): 414-25.

Pöyhönen, Pentti. 1963. "A Tentative Model for the Volume of Trade Between Countries.” Weltwirtschaftliches Archiv 90 (1): 93-100.

RISI. 2012. Industry Statistics Database (Bedford, MA: RISI).

RISI. 2013. Price Watch Database (Bedford, MA: RISI).

Roodman, David. 2009. "How to do xtabond2: An introduction to difference and system GMM in Stata.” Stata Journal 9 (1): 86-136.

Rose, Andrew K. Bilateral trade data. Accessed June 3, 2013. http://faculty.haas.berkeley.edu/arose/RecRes.htm

Sharma, Vinod K., Pieter van Beukering, and Barnali Nag. 1997. "Environmental and economic policy analysis of waste paper trade and recycling in India." Resources, Conservation and Recycling 21 (1): 55-70.

Tinbergen, Jan. 1962. Shaping the World Economy: Suggestions for an International Economic Policy. New York: Twentieth Century Fund. 
van Beukering, Pieter J. H., and Mathijs N. Bouman. 2001. "Empirical Evidence on Recycling and Trade of Paper and Lead in Developed and Developing Countries." World Development 29 (10): 1717-37.

van Beukering, Pieter, and Anantha Duraiappah. 1998. "The Economic and Environmental Impact of Wastepaper Trade and Recycling in India: A Material Balance Approach.” Journal of Industrial Ecology 2 (2): 23-42.

van Beukering, Pieter J. H., and Jeroen C. J. M. van den Bergh. 2006. "Modelling and analysis of international recycling between developed and developing countries." Resources, Conservation and Recycling 46 (1): 1-26.

Wang, Chengang, Yingqi Wei, and Xiaming Liu. 2010. "Determinants of Bilateral Trade Flows in OECD Countries: Evidence from Gravity Panel Data Models." The World Economy 33 (7): 894-915.

Windmeijer, Frank. 2005. “A Finite Sample Correction for the Variance of Linear Efficient Two-Step GMM Estimators.” Journal of Econometrics 126 (1): 25-51.

World Bank. 2012. World Development Indicators database. Accessed October 9, 2012. http://databank.worldbank.org/data/home.aspx

Zhang, Daowei, and Yanshu Li. 2009. "Forest Endowment, Logging Restrictions, and China's Wood Products Trade." China Economic Review 20 (1): 46-53. 


\section{Tables and figures}

Table 1. Summary statistics.

\begin{tabular}{lrrrrr} 
Variable & Obs & Mean & Std. Dev. & Min & Max \\
\hline Recycled paper exports & 17140 & 23.9 & 204.5 & 0.0 & 10734.1 \\
Population (exporter, exp) & 380 & 48500000.0 & 66600000.0 & 3505800.0 & 304000000.0 \\
Population (importer, imp) & 1026 & 85600000.0 & 212000000.0 & 1966800.0 & 1320000000.0 \\
Production of pulp (exp) & 380 & 6540.9 & 12558.0 & 0.0 & 59681.0 \\
Production of pulp (imp) & 1026 & 2972.2 & 8235.3 & 0.0 & 59681.0 \\
Production of recovered paper (exp) & 380 & 5507.5 & 10048.0 & 54.0 & 49356.0 \\
Production of recovered paper (imp) & 1026 & 2862.8 & 6977.7 & 25.0 & 49356.0 \\
Production of paper and board (exp) & 380 & 10984.0 & 17878.6 & 0.0 & 88181.7 \\
Production of paper and board (imp) & 1026 & 5921.5 & 13405.6 & 0.0 & 92598.5 \\
Distance & 1060 & 5793.2 & 4496.1 & 141.4 & 19537.1 \\
Export price of recycled paper (exp) & 433 & 134.8 & 50.1 & 41.8 & 354.3 \\
Export price of pulp (exp) & 428 & 547.4 & 155.1 & 0.7 & 1242.4 \\
Export price of recycled paper (imp) & 1023 & 608.2 & 8379.0 & 0.0 & 167200.0 \\
Export price of pulp (imp) & 988 & 618.2 & 385.2 & 0.7 & 3976.2 \\
Import price of recycled paper (imp) & 1100 & 181.1 & 128.6 & 27.0 & 1156.6 \\
\hline
\end{tabular}


Table 2. System GMM estimations for recycled paper exports.

\begin{tabular}{|c|c|c|c|c|}
\hline \multirow[t]{2}{*}{ 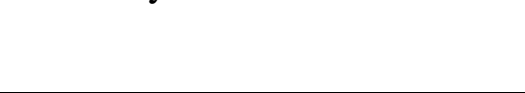 } & \multicolumn{2}{|c|}{$1990 \mathrm{~s}$} & \multicolumn{2}{|c|}{$2000 \mathrm{~s}$} \\
\hline & $(1)$ & $(2)$ & (3) & (4) \\
\hline \multirow[t]{2}{*}{ Recycled paper exports (lagged) } & $0.766 * * *$ & $0.775^{* * *}$ & $0.793 * * *$ & $0.847 * * *$ \\
\hline & $(\mathbf{1 7 . 8 8})$ & (20.76) & $(\mathbf{2 2 . 1 2})$ & (28.99) \\
\hline \multirow[t]{2}{*}{ Population (exp) } & -0.089 & -0.122 & -0.053 & -0.044 \\
\hline & $(-0.63)$ & $(-0.83)$ & $(-0.24)$ & $(-0.24)$ \\
\hline Population (imp) & $\begin{array}{l}\text { 0.210**** } \\
(\mathbf{3 . 3 3})\end{array}$ & $\begin{array}{l}\text { 0.199**** } \\
(3.86)\end{array}$ & $\begin{array}{l}\mathbf{0 . 0 8 9} * * \\
(1.97)\end{array}$ & $\begin{array}{l}0.087 * * \\
(2.24)\end{array}$ \\
\hline Production of pulp (exp) & $\begin{array}{l}-0.046 \\
(-0.57)\end{array}$ & $\begin{array}{l}-0.006 \\
(-0.09)\end{array}$ & $\begin{array}{r}0.018 \\
(0.25)\end{array}$ & $\begin{array}{l}-0.009 \\
(-0.15)\end{array}$ \\
\hline Production of pulp (imp) & $\begin{array}{l}-0.115 \\
(-1.16)\end{array}$ & $\begin{array}{l}-0.118 * * \\
(-2.02)\end{array}$ & $\begin{array}{l}-0.122 * \\
(-1.70)\end{array}$ & $\begin{array}{l}-0.116 * * \\
(-2.37)\end{array}$ \\
\hline Production of recovered paper (exp) & $\begin{array}{r}0.197 \\
(1.03)\end{array}$ & $\begin{array}{r}0.209 \\
(1.08)\end{array}$ & $\begin{array}{r}0.344 \\
(1.26)\end{array}$ & $\begin{array}{r}0.240 \\
(1.07)\end{array}$ \\
\hline Production of recovered paper (imp) & $\begin{array}{l}-0.234 \\
(-1.25)\end{array}$ & $\begin{array}{l}-0.181 \\
(-1.51)\end{array}$ & $\begin{array}{l}-0.355^{* *} \\
(-1.99)\end{array}$ & $\begin{array}{l}-0.293 * * * \\
(-2.74)\end{array}$ \\
\hline Production of paper and board (exp) & $\begin{array}{r}0.119 \\
(0.60)\end{array}$ & $\begin{array}{r}0.091 \\
(0.57)\end{array}$ & $\begin{array}{l}-0.198 \\
(-1.12)\end{array}$ & $\begin{array}{l}-0.113 \\
(-0.76)\end{array}$ \\
\hline Production of paper and board (imp) & $\begin{array}{r}0.290 \\
(1.09)\end{array}$ & $\begin{array}{l}0.228 \\
(1.43)\end{array}$ & $\begin{array}{l}0.589 * * \\
(2.53)\end{array}$ & $\begin{array}{l}0.483 * * * \\
(3.54)\end{array}$ \\
\hline Distance & $\begin{array}{l}-0.200 * * * \\
(-2.66)\end{array}$ & $\begin{array}{l}-0.228 * * * \\
(-3.26)\end{array}$ & $\begin{array}{l}-0.070 \\
(-1.34)\end{array}$ & $\begin{array}{l}-0.030 \\
(-0.69)\end{array}$ \\
\hline Border dummy & $\begin{array}{l}\text { 0.475**** } \\
(3.04)\end{array}$ & $\begin{array}{l}\text { 0.404**** } \\
(3.37)\end{array}$ & $\begin{array}{l}0.349 * * \\
(2.52)\end{array}$ & $\begin{array}{l}\mathbf{0 . 3 3 8 * * *} \\
(\mathbf{2 . 9 0})\end{array}$ \\
\hline $\begin{array}{l}\text { Relative price of recovered paper } \\
\text { and pulp (exp) }\end{array}$ & & $\begin{array}{l}-0.082 \\
(-1.00)\end{array}$ & & $\begin{array}{r}0.034 \\
(0.22)\end{array}$ \\
\hline $\begin{array}{l}\text { Relative price of recovered paper } \\
\text { and pulp (imp) }\end{array}$ & & $\begin{array}{r}0.017 \\
(0.23)\end{array}$ & & $\begin{array}{l}-0.005 \\
(-0.07)\end{array}$ \\
\hline Relative price of recovered paper & & $\begin{array}{r}0.014 \\
(0.14)\end{array}$ & & $\begin{array}{r}0.210 \\
(1.31)\end{array}$ \\
\hline Observations & 1377 & 1251 & 1672 & 1520 \\
\hline Number of groups & 260 & 244 & 276 & 269 \\
\hline Number of instruments & 182 & 214 & 199 & 220 \\
\hline \multicolumn{5}{|c|}{ Arellano-Bond test for autocorrelation in first differences (P-value) } \\
\hline $\mathrm{AR}(1)$ & 0.000 & 0.000 & 0.000 & 0.000 \\
\hline $\mathrm{AR}(2)$ & 0.442 & 0.909 & 0.415 & 0.455 \\
\hline Hansen test (P-value) & 0.122 & 0.351 & 0.089 & 0.315 \\
\hline \multicolumn{5}{|c|}{ Difference-in-Hansen tests of exogeneity of instrument subsets (P-values): } \\
\hline GMM instruments for levels & 0.078 & 0.136 & 0.019 & 0.324 \\
\hline Exogenous variables & 0.566 & 0.500 & 0.485 & 0.934 \\
\hline
\end{tabular}

Notes: z-statistics are in parentheses (*significant at $10 \%$; ** significant at $5 \%$; ***significant at $1 \%$ ). Time effects and constants are omitted from the table. The null hypotheses of the tests are as follows: 1) ArellanoBond test for autocorrelation: null $=$ no autocorrelation; 2) Hansen test of overidentifying restrictions: null = the set of instruments is valid; 3) $1^{\text {st }}$ difference-in-Hansen test: null $=$ the level moment conditions imposed in the system GMM are valid; 4) $2^{\text {nd }}$ difference-in-Hansen test: null = the variables defined as exogenous form a valid group of instruments. 


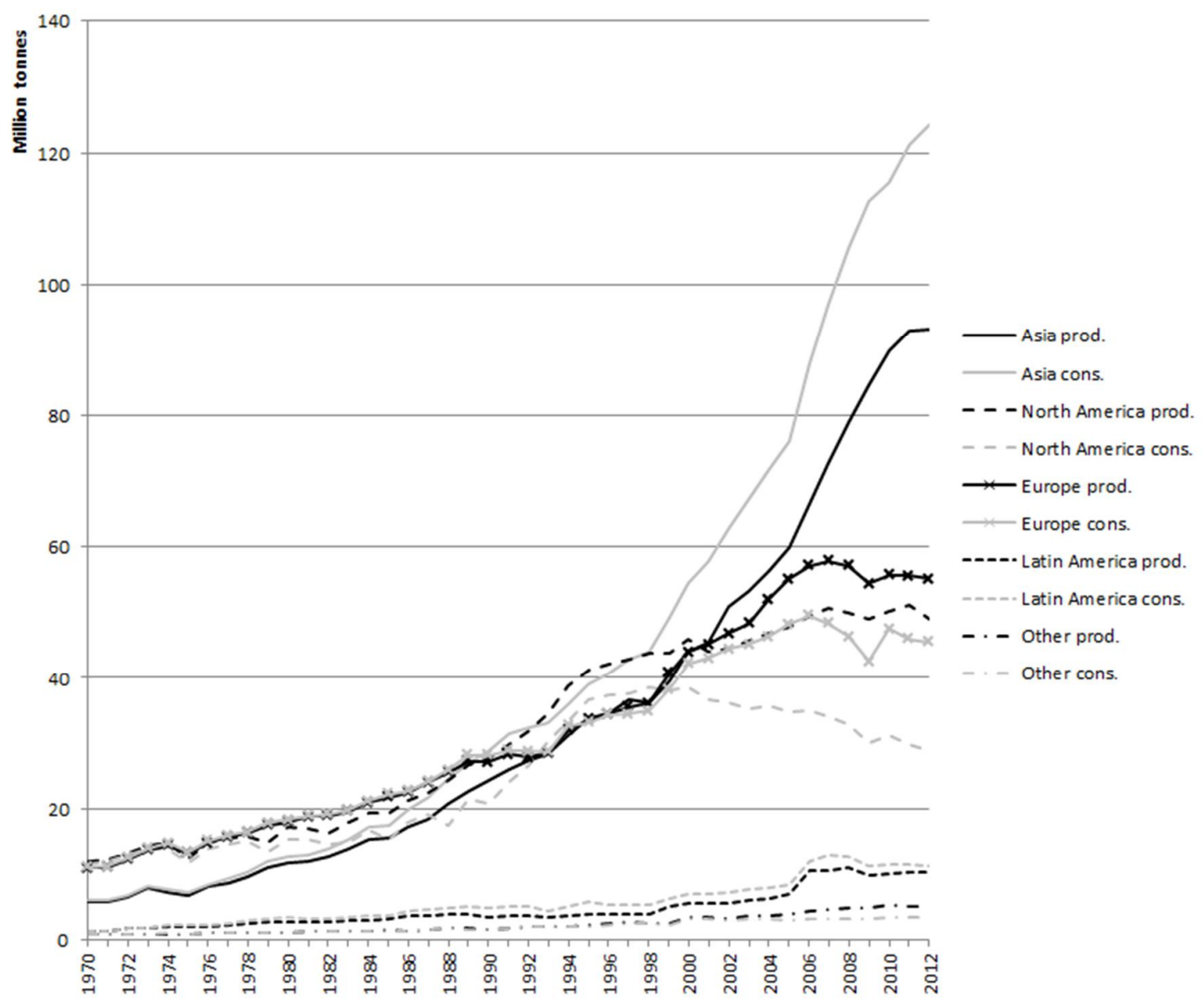

Figure 1. Recovered paper production and consumption between 1970 and 2012 by region.

(Data source: FAO [2013]) 


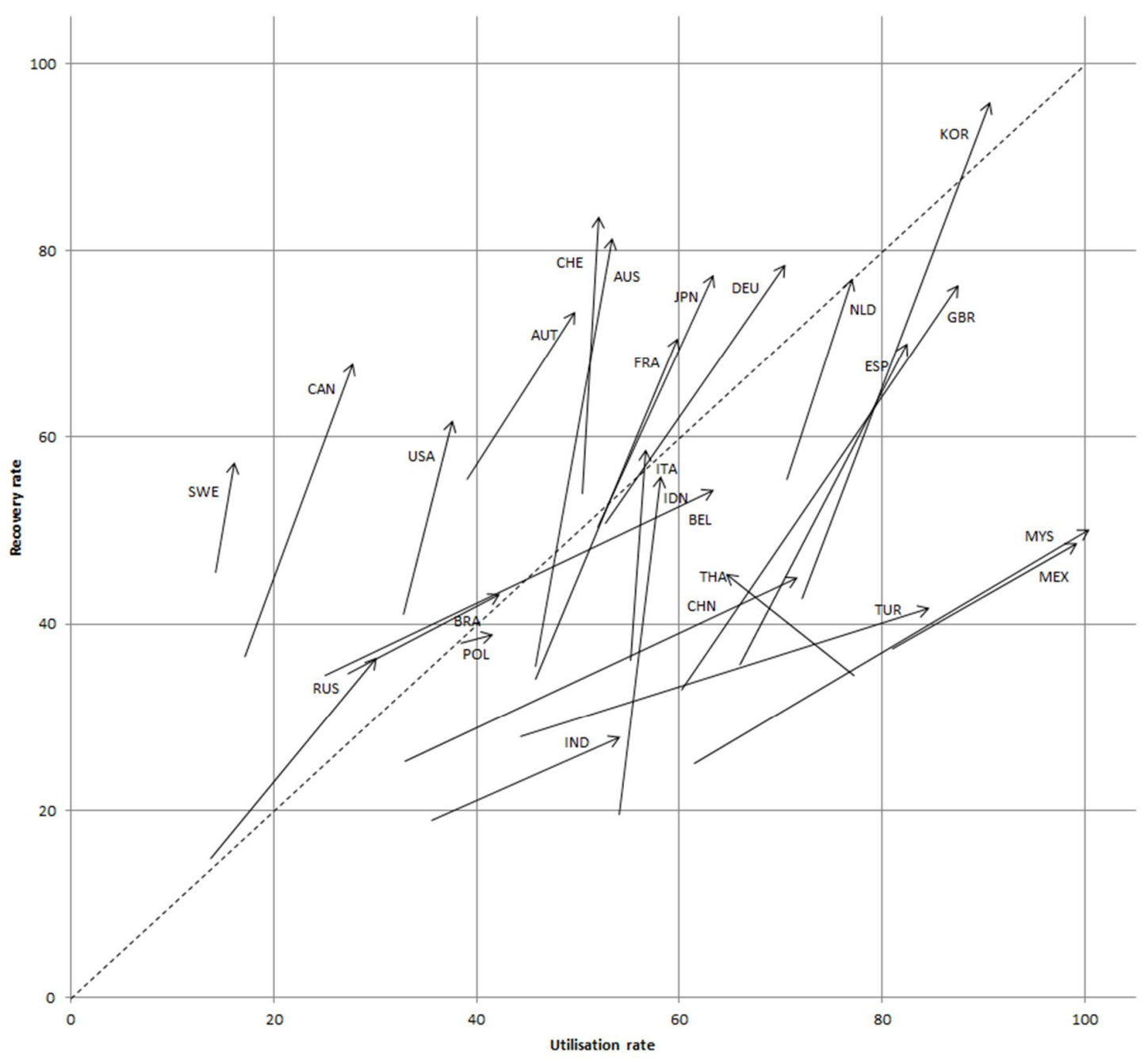

Figure 2. Changes in recycled paper recovery and utilisation rates between 1992 and 2010. (Source: authors, based on RISI [2012]) 


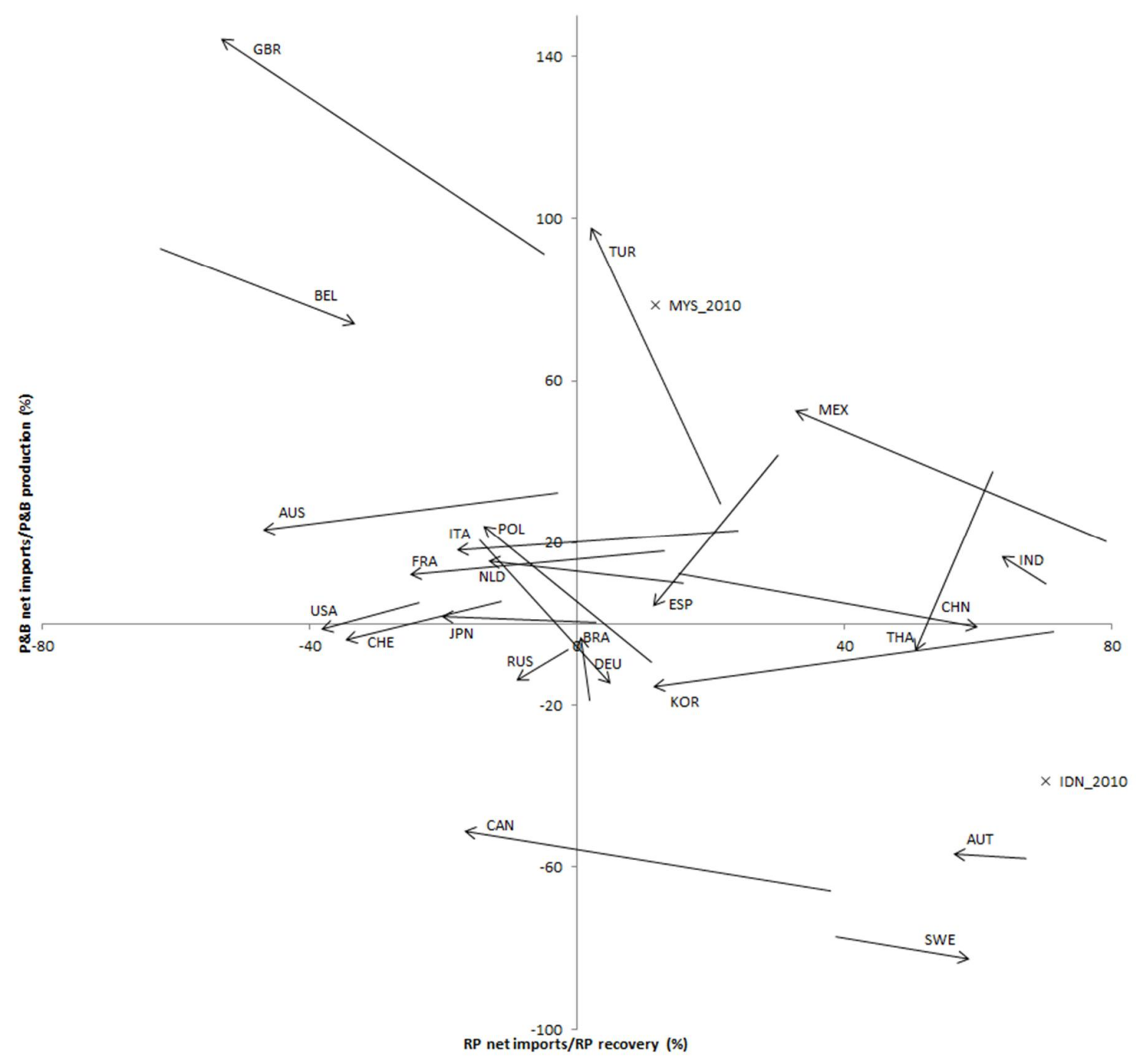

Figure 3. Changes in recycled paper and paper and board trade between 1992 and 2010. (Source: authors, based on RISI [2012])

Note: Indonesia 1992 (RP: $231.6 \%$, P\&B: -18.0 \%) and Malaysia 1992 (RP: -15.6 \%, P\&B: $188.9 \%$ ) have been omitted to enhance figure clarity. 


\section{Tables and Figures}

Table 1. Summary statistics.

Table 2. System GMM estimations for recycled paper exports.

Figure 1. Recovered paper production and consumption between 1970 and 2012 by region.

Figure 2. Changes in recycled paper recovery and utilisation rates between 1992 and 2010.

Figure 3. Changes in recycled paper and paper and board trade between 1992 and 2010. 